\title{
THE USE OF QR-CODES IN TEACHING A FOREIGN LANGUAGE TO THE FUTURE EDUCATORS
}

The rapid development of information and communication technologies significantly affects all spheres of human life. According to the research, the representatives of the internet (digital) generation (generation Z), the young people who are mostly the students of higher educational institutions, are considered to be a special category concerning the perception and analysis of information.

One of the interesting modern information and interactive technologies is the use of QR-codes, which is an interactive Internet technology that encourages students to learn the program material.

The article deals with the peculiarities and main advantages of the use of QR-codes in teaching a foreign language to the future educators, because the teachers have to become the main helpers in mastering effective innovative technologies and techniques in students' acquisition of new knowledge, especially in learning foreign languages. In turn, knowledge of a foreign language greatly facilitates the work with modern innovative technologies, and, consequently improves the life.

In the educational process with the help of QR-codes one can make direct links to the regulations, curriculum, educational program, annotation to the discipline, article, schedule, announcements, news of the department, university; encode the links to a specific online resource that is needed for learning, thus significantly saving students' time (e.g., links to educational videos); encode a text or a fragment of it, a sentence or a part of it, various images, tables with grammatical rules, etc.; hide the task algorithms or rules that are difficult to remember; create an automated transition to online testing, statistical surveys, questionnaires, etc.; acquaint students with interesting scientific facts or the historical event of the current day; create a quest or interactive game; wish students a good day / weekend / holiday on behalf of the department administration and lecturers, etc. Besides, the examples of the tasks using QR-codes proposed to the future teachers are given.

Key words: information and communication technologies, QR-code, generation Z, educator, foreign language, higher educational institution.

\section{(статтю подано мовою орихіналу)}

The modern world is overfull with different high-tech products and a whirlpool of information processes. As new information technologies have been implemented practically in all the spheres of life, this state of affairs obliges everyone to be able to work with them, to process large amounts of information with their help. The lives of contemporary people are full of mobile devices that serve a variety of purposes. Their use has become a necessity, and sometimes a habit, especially for children.

According to the devices used in perception and analysis of information people can be conditionally classified into the following groups:

1) internet (digital) generation (15-24 years);

2) computer generation (25-44 years);

3) television generation (45-64 years);

4) radio generation (65+ years) [7].

Consequently, nowadays most of the representatives of the internet (digital) generation (generation Z) study in higher educational institutions. Perception and analysis of information is their characteristic feature. They do not appreciate clear schedules and deadlines, the responsibilities for them are like a quest: did, took the award, went on. This is the digital generation, because they are interconnected through the Internet, YouTube, smartphones, etc. Modern students can't imagine their life without it, because they perform most of their daily activities using gadgets: social networking, watching movies, entertainment, searching for information, listening to music, etc.

In order to avoid the misunderstanding between teachers and students it's necessary not only know and understand the behavior of the new generation, psychologically correctly respond to it, but also constantly improve the own information literacy and use modern gadgets in the educational process. One of the interesting modern information technologies is the use of QR-codes, which doesn't require boring reading of textbooks, on the contrary it is an interactive Internet technology that encourages students to learn the program material.

Due to the project of the conception of the New Ukrainian School communication in foreign languages and information and digital competence are included in the list of 10 key competencies [2]. Consequently, the problem of use of new modern information technologies such as QR-codes in the process of future teachers' training is of great topicality.

Many scientific works are devoted to the problem of the use of modern information and communication technologies (ICTs) in teaching a foreign language in secondary schools: Yu. Putiienko and A. Fokina study the use of QR-codes at the English classes [3; 5], I. Sokol and O. Sopina reveal the possibilities of using ICTs in teaching English (Web 2.0 services (Plickers, learningapps, QR-codes), as well as mobile phones photo, video, dictaphone)) [4], S. Kozyr offers the students a QR-quest to check the level of their knowledge of English [1], etc. At the same 
time the attention to teaching foreign languages to future educators with the help of QR-codes technology has not been paid, which determines the relevance of the chosen topic. Therefore, the purpose of the article is to study the peculiarities of the use of QR-codes in teaching a foreign language to the future educators.

A QR-code (a quick response code) - is a two-dimensional barcode that allows people to encode any information - texts, web links / standard URLs for websites, phone numbers, videos, audios, images, documents, 3-dimensional spaced objects, "virtual stores", bank accounts information or credit cards information, different instructions, also can be used in restaurant ordering, for joining Wi-Fi networks, in creating video games, generating timebased one-time passwords, product tracing, loyalty programs by retail outlets, counterfeiting detections, encoding the information on tombstones and for many other purposes. The QR code is visually represented in the form of a black and white square, resembling a maze. QR codes include three squares designed to orient and define the boundaries of the entire encoded image, and separate pixels that are located in the area between these squares. These pixels, in fact, carry the encoded content.

In one QR-code 7089 figures, 4296 symbols or 1817 hieroglyphs can be encoded. The code can contain any text combination consisting of figures and symbols [6]. A QR-code is a ready image, that can be saved in the jpeg, png, tiff, svg, eps, $p d f$ formats and placed in a web-site, published and shared in social networks, printed on any surface or installed into the smartphone, that will allow the subscriber to save any text information in his mobile devise, follow the links, send the SMS, etc. Such graphic signs are an improvement of the linear barcodes.

The main advantages of QR-codes over regular barcodes are:

1) the ability to get instant access to any information in the Internet using smartphones and scan with a regular smartphone camera a large amount of encoded information of any kind;

2) high recognition speed even with a very small size of printed code;

3) can be placed on any surface;

4) high level of target audience coverage;

5) damage resistance.

QR-codes were firstly used in engineering in 1994 in Japan, but now they are used practically everywhere. Besides, they are also widely used in education: in conducting quests and educational tours, creating a hidden hint, conducting interesting surveys, writing QR-books, etc. [4].

In the modern system of the Ukrainian education, much attention is paid to the optimization and technologicalization of the educational process. The dynamic development of information technologies and mass distribution of mobile devices creates the opportunities for use of such universal information carrier as QR-code.

Most of the modern student's daily chores are done using a smartphone or other gadgets. With this in mind, we believe that the purposeful use of the ICTs in the educational process will encourage students to enjoy learning the material and gain new knowledge.

Mastering this technology is one more step to increase the level of students' IT competence: they learn to use ready-made QR-codes, as well as understand what information can be encoded, learn how to create such forms, the purpose of it, what to do with this code then, learn to understand how to use this knowledge in the learning process and why it is needed.

Besides, with the help of QR-codes one also can:

- make direct links to the regulations, curriculum, educational program, annotation to the discipline, article, schedule, announcements, news of the department, university, etc.;

- encode the links to a specific online resource that is needed for learning, thus significantly saving students' time (e.g., links to educational videos);

- encode a text or a fragment of it, a sentence or a part of it, various images, tables with grammatical rules, project works etc.;

- hide the task algorithms or rules that are difficult to remember;

- create an automated transition to online testing, statistical surveys, questionnaires, etc.;

- to acquaint students with interesting scientific facts or the historical event of the current day;

- create a quest or interactive game;

- wish students a good day / weekend / holiday on behalf of the department administration and lecturers, etc.

To make the own QR-code the lecturer will need the Internet and the information to be encoded. Among the Ukrainian web resources for creating QR-codes can be distinguished the following: http://ua.qr-code-generator. com, http://qrcodes.com.ua/, http://www.qr-code.com.ua, etc. There are a lot of programs for reading such codes. In most modern smartphones they are already installed, but if there aren't such, the person has to enter into the App Store: for Andriod - Play Market, for iOS - iTunes [6].

QR-codes can be used at different stages of the class, besides, during different forms of work (individual, pair, group). QR-code is one of the directions of augmented reality. It combines real and virtual settings and can be used not only electronically but also as a handout.

Let us give some examples of the tasks which can be proposed to the future educators while studying the topic "Teaching as a career".

Task 1. Read the encoded poem and name the reasons that made you choose the career of a teacher. Who influenced your choice of a career? 


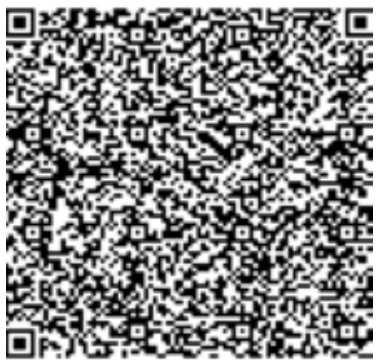

Task 2. Study the grammar material on the types of the conditional sentences in English and give your own examples on each type related to the topic "Teaching as a career".

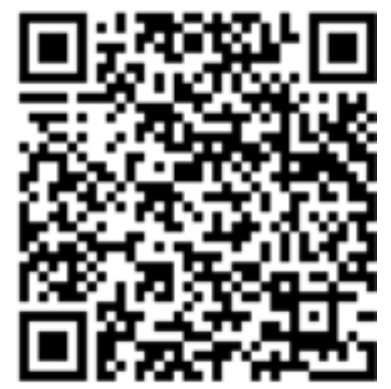

Task 3. Open the brackets in the following sentences and change the verbs in them according to the type of the conditional sentence named by the lecturer. (The students are showing the encoded answers on their smartphones to the lecturer. The lecturer is checking the students' answers with his smartphone standing in front of them.)

The proposed sentences:

1. If you (to be) more attentive, you (not to make) so many mistakes in your test.

2. If Mike (not to feel) bad last night, he (to do) his home assignment.

3. If you (to read) a lot in English, you (to make) much progress in speaking.

4. If the teacher (to explain) the meaning of that phrase, I (not to ask) so many questions.

5. If I (to review) all the topics for the exam, I (not to fail) it.

6. If you (to work) hard at your pronunciation, you (to become) a successful interpreter.

7. If I (to pass) all my final exams successfully, I (to get) a Master's Diploma.

8. If you (to fall) behind the group, you (to be sent down).

9. If her parents (can, to afford), she (to go) to a private boarding school which offers a very high-quality education.

10. If he (to have) an inclination for languages, he (to make) a successful career of a diplomatist.

11. If the exams (to start) earlier, we (to have) longer holidays.

12. She (to buy) this teaching aid, if she (to have) such an opportunity.

13. If you (to be) more diligent student, you (to get) a scholarship.

14. If I (to be) a teacher, I (to give) difficult exams to my students.

15. If I (to be) the Minister of Science and Education of Ukraine, I (to make) some changes into the curriculum.

16. I (to look) for a job, if I (to be) a university graduate.

17. If I (to do) all my best, I (to pass) my final exam with honor.

18. If he (to be) more active, he (to take) the floor.

19. I (to attend) a course of lectures under this professor, if I (to have) time.

20. If she (to be) well-equipped for teaching, she (to have) a happy and satisfying life.

The lecturer can diversify doing the task by the students proposing them the ready variants of the sentences. The students' task will be to choose the correct, to their mind, answer.

Task 4. Listen to the story very attentively and make a list of pros and cons of being a teacher (the students are watching the video).

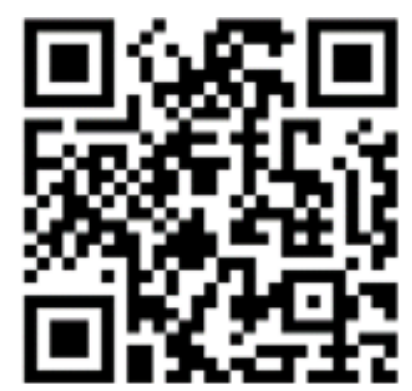


Task 5. Work in three groups (the lecturer is grouping the students giving each group one of the tasks:

1) Read the article and encode the reasons of teachers' burning out (each statement must be encoded with a separate QR-code);

2) Read the article and encode the teachers'burn out signs and symptoms (each statement must be encoded with a separate QR-code);

3) Read the article and encode the teachers'burn out prevention and solution (each statement must be encoded with a separate $Q R$-code).

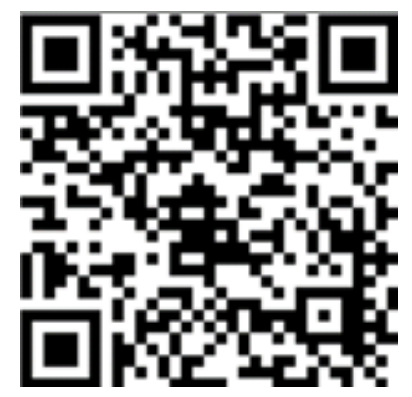

Then each statement is printed out on paper and the students must decide whether the statement refers to the reasons of teachers' burning out, the teachers' burn out signs and symptoms or the teachers' burn out prevention and solution)

Task 6. Work in pairs. Place the parts of the text "What are we for our pupils?" in the correct order:
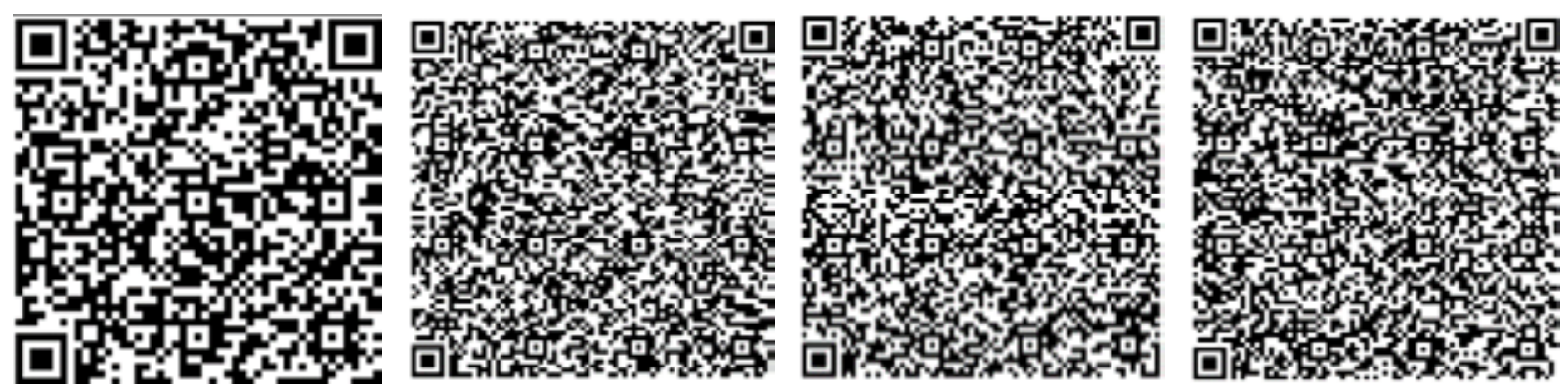

Task 7. Making projects. Write a letter of recommendations to the future generation of teachers in the instructive form and encode it with a colorful QR-code.

Task 8. The students are given the halves of $Q R$-codes with encoded proverbs. The task is to find the appropriate halves:
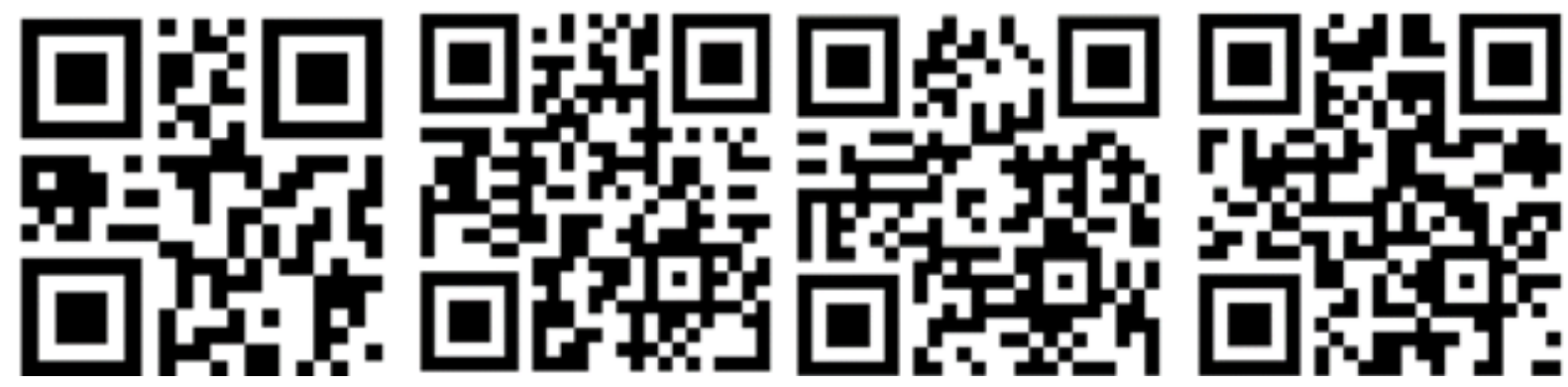

Conclusions. Taking into account that QR-codes provide many opportunities in everyday life, these images can also be a meaningful addition to the classes, including in higher educational institutions.

The use of modern information and communication technologies, including QR-codes, as well as various methods of working with them, significantly improves the future educators' level of learning foreign languages, increases students' motivation to learn, intensifies their learning activities, individualizes the learning process, expands the boundaries of students' independent activity, diversifies the forms of information presentation, varies the methods and types of tasks, makes classes more creative and innovative. In turn, mastering a foreign language opens the access to information technologies and various disciplines, the research done within which is often made public in the reports at the international conferences. ICTs enable future professionals in the field of education to reach the international level of communication and, consequently, cooperation.

\section{Bibliography:}

1. Козир C.I. QR-квест “Interesting English” URL: https://englishkozyr.webnode.com.ua/qr-kvest-interesting-english/ (дата звернення: 12.02.2021). 
2. Проєкт концепції Нової української школи / За заг. ред. Грищенка М. 2016. 36 с. URL: http://osvita.ua/doc/files/ news/520/52062/new-school.pdf (дата звернення: 12.02.2021).

3. Путієнко Ю. Б. Інтерактивні матеріали “QR коди” на уроках англійської мови URL: https://vseosvita.ua/library/interaktivnimateriali-qr-kodi-na-urokah-anglijskoi-movi-177877.html (дата звернення: 12.02.2021).

4. Сокол І., Сопіна О. Використання сучасних інформаційно-комунікаційних технологій у викладанні англійської мови. Комп'ютер у школі та сім'ї. 2016. № 7.

5. Фокіна А. I. Використання QR-кодів на уроках англійської мови. НВК “ЗОШ I-III ст. № 2-ліцей”. 2020. URL: https:// nvk2nemyriv.net.ua/novini/mk-uchiteliv-inozemnih-mov/vykorystannya-qr-kodiv-na-urokah-anglijs/ (дата звернення: 12.02.2021).

6. Що таке QR-код та як його використовувати вчителю? Незалежна Освітня Корпорація TeachHub. URL: http://teach-hub. com/scho-take-qr-kod-ta-yak-joho-vykorystovuvaty-vchytelyu/ (дата звернення: 12.02.2021).

7. Trávníček, J. Česká čtenářská republika. Generace fenomény životopisy. Brno: Host. 2017. 445 s.

\section{References:}

1. Kozyr S.I. QR-kvest “Interesting English" [QR-quest "Interesting English"] URL: https://englishkozyr.webnode.com.ua/qrkvest-interesting-english/ (The last access date: 12.02.2021) [in Ukrainian, English].

2. Proiekt contseptsii Novoi ukrainskoi shkoly. Za zah. red. Hryshchenka M. (2016). [The draft of the New Ukrainian school concept] URL: http://osvita.ua/doc/files/news/520/52062/new-school.pdf (The last access date: 12.02.2021) [in Ukrainian].

3. Putiienko Yu.B. Interaktyvni materialy "QR kody" na urokakh anhliiskoi movy [Interactive materials "QR codes" at the English classes URL: https://vseosvita.ua/library/interaktivni-materiali-qr-kodi-na-urokah-anglijskoi-movi-177877.html (The last access date: 12.02.2021) [in Ukrainian].

4. Sokol I., Sopina O. (2016). Vykorystannia suchasnykh informatsiino-komunikatsiinykh tekhnolohii u vykladanni anhliiskoi movy. Kompiuter u shkoli ta simi [The use of modern information and communication technologies in teaching English. Computer at school and family] [in Ukrainian].

5. Fokina A.I. Vykorystannia QR-kodiv na urokakh anhliiskoi movy. NVK "ZOSH I-III st. \# 2 litsei” [The use of QR-codes at the English classes. EC "School I-III st. \# 2-lyceum”] URL: https://nvk2nemyriv.net.ua/novini/mk-uchiteliv-inozemnih-mov/ vykorystannya-qr-kodiv-na-urokah-anglijs/ (The last access date: 12.02.2021) [in Ukrainian].

6. Shcho take QR-kod ta yak yoho vykorystovuvaty vchyteliu? Nezalezhna Osvitnia Korporatsiia TeachHub [What is a QR-code and how to use it?] URL: http://teach-hub.com/scho-take-qr-kod-ta-yak-joho-vykorystovuvaty-vchytelyu/ (The last access date: 12.02.2021) [in Ukrainian].

7. Trávníček, J. (2017) Česká čtenářrská republika. Generace fenomény životopisy. [Czech Readers’ Republic. Generation phenomena biographies] Brno: Host. [in Czech].

\section{Мірошник I. В. Використання QR-кодів у навчанні іноземної мови майбутніх педагогів}

Швидкий розвиток інформаиійно-комунікаиійних технологій суттєво впливає на всі сфери людського життя. Згідно з науковими дослідженнями, представники Інтернет (цифрового)-покоління (покоління Z) - молоді люди, які є переважно студентами вищих навчальних закладів, - вважаються особливою категорією щцодо сприйняття та аналізу інформаиії.

Однією з цікавих сучасних інформаційних та інтерактивних технологій є використання $Q R$-кодів, щуо являє собою інтерактивну Інтернет-технологію, яка заохочує студентів до вивчення програмового матеріалу.

У статті розглядаються особливості та основні переваги використання QR-кодів у навчанні майбутніх викладачів іноземної мови, адже вчителі мають стати головними помічниками в оволодінні ефективними інновачійними технологіями та прийомами в отриманні учнями нових знань, особливо під час вивчення іноземних мов. Своєю чергою знання іноземної мови значно полегшує роботу з сучасними інноваційними технологіями, а отже, покрашує життя людини.

У навчальному процесі за допомогою QR-кодів можна робити прямі посилання на нормативно-правові документи, навчальні плани, освітні програми, анотаиї до дисииплін, статті, розклад, оголошення, новини кафедри, університету, кодувати посилання на конкретний Інтернет-ресурс, який необхідий для навчання, тим самим значно заощаджуючи час студентів (наприклад, посилання на навчальні відео), закодувати текст або його фрагмент, речення або його частину, різні зображення, таблиці з граматичними правилами тощяо, приховати алгоритми завдань або правила, які важко запам'ятати, створити автоматизований перехід на онлайн-тестування, статистичні опитування, анкетування тощя, ознайомити студентів з цікавинками науки або історичною подією поточного дня; створити квест або інтерактивну гру, побажати студентам приємних вихідних / канікул дня від адміністрації факультету та викладачів тощо. Крім того, у статті наведено приклади завдань із використанням QR-кодів, запропонованих майбутнім викладачам для навчання їх іноземної мови.

Ключові слова: інформачійно-комунікаційні технології, QR-код, покоління Z, педагог, іноземна мова, заклад вищої освіти. 